\title{
ON THE MINUTE STRUCTURE OF STROMATOPORA AND ITS ALLIES.
}

BY DR. C. ROMINGER.

I had only recently the opportunity of reading the joint essay by Prof. Alleyne Nicholson and Dr. F. Murie on the structure of Stromatopora, published in 1879, in the Journal of the Linnæan Society of London. The communication treats for the most part to the structure of the Stromatoporas found on the American continent.

As I had paid attention for a number of years to the study of Stromatopora and had gathered extensive collections of them in most of the localities from which the type specimens described by these authors came, I had no difficulty in identifying the forms they had under consideration. While I was enabled in this way to confirm the correctness of some of their observations, I found that in other instances they labored under erroneous conceptions, partly because their material was insufficient, partly because they did not recognize the things as they actually were.

Of most of the forms described by them and of a number of others I had over fifteen years ago worked out descriptions, accompanied by sixteen plates of magnified photographic figures, intending to have them published under the auspices of the Smithsonian Institution. Those to whom the paper was referred for examination, however, reported adversely, in view of the recent publication of Baron v. Rosen's monograph on Stromatopora and the undesirability, as they believed, of issuing so many plates with such a comparatively small amount of text.

Messrs. Nicholson and Murie commence with an historical exposition of the different opinions held by writers on the nature and affinities of Stromatopora, and after discussion of the arguments for and against such opinions, they declare themselves with some reserve in favor of the most popular of them, which was also held by Goldfuss, the founder of the genus, that is to say, they think the nearest relationship of Stromatopora is with the sponges having a calcareous skeleton. The authors think they have recognized in Stromatopora systems of channels destined for the circulation of water to and from the organism, analogous to those permeating the mass of sponges; but we shall see hereafter that these supposed 
water-channels are not a part of the organism, and prove on accurate examination to be either accidental perforations of the skeleton by boring animals, or else, are the stems of certain corals, particularly of Syringopora, which have grown up simultaneously with the Stromatopora, parasitically enveloping them.

At the time I wrote the before-mentioned manuscript I also believed a close affinity existed between the sponges and Stromatopora, but since Carter and others have pointed out the similarity existing between the calcareous skeleton of Hydractinia and Stromatopora I am convinced that the similarity between the calcispongiæ and Stromatopora is merely an external one. The mode of growth and organization of the sponges essentially differs from that of Stromatopora. The sponges are through their entire mass permeated by a system of channels systematically arranged so as to make it evident that all parts of the sponge are destined to perform simultaneously a vital function in the compound organism. There is nothing in their structure which could with propriety be compared with the uniform periodicity in the growth of a Stromatopora, which forms layer after layer in endless succession, one being the exact analogue of the other. The layers in many instances are almost entirely shut off from communication with the subjacent portion of the laminated skeleton. We have to infer, therefore, that the live portion of a Stromatopora was confined to the uppermost superficial strata, while the interlaminar cell-spaces towards the interior gradually were abandoned and became dead portions of the skeleton, as is the case with the skeletons of Hydractinia, and generally with all true corals producing a calcareous stony skeleton.

In a second chapter the authors give the characteristics of Stromatopora, considering as type of the genus the Goldfussian species Str. concentrica and polymorpha, both found in the Eifel, Germany.

Their description reads : "Stromatopora is composed of a succession of thin, close-set laminæ, arranged concentrically round one or more imaginary centres. These concentric fundamentally horizontal laminæ are separated by interspaces, which are crossed by more or less numerous vertical pillars; hence the vertical section of a Stromatopora exhibits a number of approximately horizontal layers and intervening spaces, the latter divided by upright pillars into a number of vesicular compartments. The entire lami- 
nated mass has sometimes grown as an incrustation of a central nucleus, a shell or coral; other times it forms a more or less thick expansion with a small point of attachment, and otherwise a free underface covered by a wrinkled dense epithelial crust."

After this, in a general way correct description, they discuss the original nature of the hard structures of Stromatoporoids, which in fossilized condition are found calcareous, other times siliceous, or partially calcareous and partially siliceous ; and demonstrate the originally calcareous nature of the ske eton of Stromatopora particularly by the circumstance that the specimens of Stromatopora are always found in a calcareous condition, when the associated fossils are likewise calcareous; but if the associated primitively calcareous fossils are to any large proportion silicified, then also the skeletons of Stromatopora are found more or less completely silicified. The various modes of preservation are then enumerated: $a$, skeleton wholly calcareous; $b$, skeleton calcareous, interlaminar spaces infiltrated with silica; $c$, skeleton silicified but the interlaminar spaces infiltrated with calcite; $d$, both former conditions of preservation represented in one and the same specimen; $e$, both skeleton and interlaminar spaces transformed and filled with silica.

Entering into description of the more minute particulars of the structure of Stromatopora the writers state that of the beforementioned pillars not all reach from lamina to lamina, but that rudimentary shorter ones occur between. The pillars and laminæ are represented as composed of granular carbonate of lime, which shows no structure, except occasionally an indistinct indication of reticulation. According to my own observation, in all wellpreserved calcareous specimens of Stromatopora, the substance of the laminæ and of the pillars, being composed of a network of interwoven delicate fibres, can be recognized with the greatest distinctness, with a good simple lens, although not so distinctly with the higher powers of a microscope, both the organic structure and the crystalline mineral structure then becoming visible, thus causing a blurred image.

The pillars are described as either simple rounded prominences or else as vermicular and anastomosing crests which are imperforate, solid, not tubular. The writers, however, observed on the surface of weathered silicified specimens sometimes a part of the exposed pillars perforated by a central opening, which they try 
to explain by an incomplete silicification of the central portion of these pillars and by subsequent lixiviation of the unchanged calcareous centre on exposure to atmospheric influences.

I have, likewise, frequently observed a central perforation of cross-fractured pillars in calcareous, as well as in silicified specimens, but while I perfectly agree with their representation of the pillars as generally being solid, not tubular, I do not think that the central perforation of the pillars in the mentioned cases is the result of weathering of the imperfectly silicified skeleton substance. I believe it is caused by funnel-shaped inflexions of the laminæ at the base of these pillars, which excavation shows itself as a central opening, if the apical part of the pillars which is solid is broken off.

The laminæ of some forms of Stromatopora, such as tuberculata, and granulata of Nicholson, are described as continuous leaves, without any visible perforations placing the superimposed interlaminar spaces in communication. It may be suggested that such openings of communication may exist. I had frequently occasion to observe this to be the case, although, in many instances, the laminæ of these species of Stromatopora appeared perfectly free of larger perforations than the minute pores of the tissue itself.

In other forms, such as Strom. nodulata, and densa, the existence of such larger openings for communication between the superimposed interlaminar spaces has been recognized by the writers.

According to my own observations, a part of these pores of communication, and at the same time the largest ones, can be determined to be portions of the ramified horizontal channel expansions radially converging towards certain centres, and uniting there in one larger central canal, ascending vertically. These horizontal canals in their extension slowly ascend from one interlaminar space into another. They have, as Messrs. Nicholson and Murie correctly observed, no proper walls, and cannot be considered as canals horizontally intersecting the substance of the laminæ, but with more propriety are described as furrows on the surface of the laminæ, which, finally, by the formation of a new lamina above the older one, become roofed over and are transformed into closed tubular spaces. This opinion I fully indorse.

All Stromatoporas do not exhibit such radical channel expansions well developed, but faint indications of radially arranged 
furrows converging to certain centres can be discovered in almost every form of Stromatopora if we examine a sufficient number of well-preserved specimens. Certain forms show them always most beautifully, particularly those in which the tissue of the lamellæ and the pillars has an open porous texture, which increases their bulk, and diminishes the size of the interstitial spaces proportionately. These forms have been pointed out by Winchell under the generic name of Conostroma, which distinction is not accepted by Messrs. Nicholson and Murie, as the principal generic character of Cœnostroma is said to be the occurrence of the radial channel expansions which, being present in forms of very different affinitives, cannot, in their opinion, be used as a generic mark. This is, in one way, true; but if we consider that the forms comprehended under Conostroma are distinguished not only by their radiated surface, but by the before-mentioned bulkiness of their laminæ and pillars, and the minuteness of the interlaminar cavities, from the ordinary typical forms of Stromatopora, which have compact, well-defined laminæ and pillars, I think these two characters combined allow a subdivision of Stromatopora into two groups, which at the first glance are distinguishable by even an inexperienced observer, although, as I admit, numerous transitory grades from one group to the other exist, which make it difficult to draw a line of demarkation between them.

The characters by which Prof. Nicholson distinguishes Stylodiclyon from Stromatopora most assuredly stand on a weaker basis than those of Winchell's Conostroma, as I will demonstrate hereafter when Messrs. Nicholson and Murie's newly created genera are reviewed.

After having described these radiating horizontally expanded channels, the authors give a description of certain so-called vertical water canals, observed in many different forms of Stromatopora.

There are two essentially different kinds of such canals vertically traversing the laminated masses, and considered by the authors as parts of the organism. In one of the cases we find the mass of the Stromatopora perforated by comparatively large, generally round, but sometimes elliptical canals, which have no walls for themselves, and are evidently perforations by boring animals. The nature of the channels and their totally irregular distribution in the masses, proves this in a large number of specimens examined by me. 
As representing this kind of channels, or oscula, as they term them, the authors mention the following forms: Stromatopora striatella, Hindei, tuberculata, ponderosa, and ostiolata. In the first four mentioned forms, the true nature of these perforations is without difficulty demonstrable. In St. ostiolata, of which specimens from Guelph, Canada, are transformed into a coarsely crystalline dolomite, the organic structure of these masses can scarcely be ascertained, and it is impossible to decide definitely on the nature of the tubular casts traversing them. One of the other examples mentioned, the so-called Stromatopora Hindei, is unfortunately selected, as it is in reality an Alveolites, perforated by some boring animal. The figures and description given leave no doubt as to this point. Similar silicified specimens are, moreover, not rarely met with in the Niagara group of Michigan.

The second kind of vertical tubular channels supposed to have the function of conducting water through the organism of Stromatopora has distinct walls with imbricating wrinkles of growth on the outside, and frequently from their interior a circle of longitudinal rows of spinules projects; more rarely invaginated funnel-shaped diaphragms interrupting the tube-channels can be observed, all of which proves that we have before us inclosed stems of a Syringopora and not canals making part of the skeleton of the associated Stromatopora. Specimens of each are quite abundant in the Devonian strata of Michigan, Ohio, Kentucky, and Canada. Some pebbles found on the shore of Lake Superior represent the same parasitical investment of clusters of Syringopora stems on Stromatopora.

In the Niagara group we also find various kinds of Stromatopora similarly intergrown with stems of a delicate Syringopora, which I have described in the Michigan Geological reports under the name Syringopora filiformis. In other cases we find colonies of Diphyphyllum multicaule invested in the same way by Stromatopora.

In this connection also Stromatocerium of Hall is cited by the authors as an example of the first class of vertical water canals, without any proper walls. In a chapter headed "Departures from the Ordinary Type of Stromatopora," as the first of these, Stromatocerium is enumerated, and the following description given : "It has the general aspect of Stromatopora, and possesses crowded concentric laminæ characteristic for Stromatoporoids. The laminæ are 
of considerable thickness, and are separated as usual by wellmarked interlaminar spaces, but the latter are quite open, and there is a total absence of the vertical calcareous pillars which occur in the normal Stromatoporoids; but the whole mass is perforated by innumerable vertical canals, which are destitute of walls, and open directly into the successive interlaminar spaces which they penetrate, as well as into open irregular laminæ in the general laminated skeleton."

This is an erroneous conception of the structure of that family, as these supposed tubules are in reality casts of actual solid tissue pillars which vertically intersect the laminated mass, sometimes without interruption in the different intersected layers, sometimes in each band (consisting of a group of subordinate delicate layers), these pillars start anew from a fresh basis.

The ordinary mode of preservation of the fossil has generally impaired the original organic texture of the skeleton, which became almost totally destroyed, and the space occupied by tissue mass filled with transparent crystalline carbonate of lime, while the former vesicular interlaminar interstices were replenished with turbid, milky dolomite. Sections through such specimens in vertical direction, show the transparent casts of the tissue pillars as tubular channels, and in horizontal sections the same appear to be circular orifices surrounded by a massive interstitial wall substance.

Silicified specimens occasionally occur in which the interlaminar spaces filled with silica are the only part preserved, while the actual skeleton has been removed by solvents, and the space once occupied by it remaining hollow, we then see the mass intersected by innumerable small circular channels.

I had the good fortune to find in the drift of Ann Arbor some calcareous specimens in which the original tissue mass is preserved, represented by a non-transparent, dull, calcareous matter, while the cellulose interlaminar interstices are replenished with clear, transparent carbonate of lime.

They consist of a succession of thick, concentrically superimposed, undulating and monticulose layers from two to six millimeters in thickness, which are generally demarkated from one another by darker colored division lines of greater density than the remainder of the lamina. Each such larger lamina represents a certain uninterrupted period of growth during 
which, beginning from a solid basal leaf, densely crowded with papillose prominences, delicate versiculous plates are formed at short intervals, connecting into a floor which bridges over the tops of these papilli, which are prolonged until another floor spreads over their apices, and until from six to twelve of these subordinate laminæ had formed, inclosing between them versicular cell-spaces. Then after an evident interruption in the uniform progress of growth, a new one of the larger layers composed of subordinate laminæ, commenced to form on top of the other. The pillars intersecting the laminæ subordinate to a larger bandlike layer form uninterrupted columelles which usually correspond with those of the next succeeding layers or bands. In other cases, however, the columellæ or pillars of each one of the thicker compound laminæ are independent in their position, and do not correspond. Some of these pillars are often much stouter than the others, and divide into several mammiform side branches. The majority of them are simple, rounded, or laterally compressed into vermicular crests, particularly so in the circumference of the monticulose prominences of the surface, where these crests radially converge towards the centre, resembling the horizontal radially converging channel expansions of an ordinary Stromatopora, but in this case it is the tissue-mass, and not the intervening furrows, which produces the vermicular radiating converging lines. The interstitial cell-spaces inclosed between the convex transverse leaflets bridging over the space from pillar to pillar, are very similar to the convex vesicules in a vertical section of a Cystiphyllum. As above stated in the majority of specimens occurring abundantly in the Trenton group of Escanaba River, and at Nashville, Tennessee, and also in the drift of Ann Arbor and in the upper part of the Cincinnati group at Madison, Indiana, the actual skeleton sub. stance is almost completely destroyed, and its place filled with crystalline carbonate of lime. It often occur's that several of the thick bandlike layers are composed of a succession of vesiculose layers twice or three times the size of the vesicules composing other layers of the same specimens. In this case the vertical pillars become very obscure, so that the whole appears as an indiscriminate accumulation of vesicules as large as those of an ordinary Cystiphyllum.

The surface of Stromatocerium was not known to Messrs. 
Nicholson and Murie. I have seen many specimens with a surface covered by rounded monticules similar to those of Stromatopora monticulifera, Winchell, and the tops of these monticules radiated by the convergence of the before-mentioned compressed vermiform crests representing the pillars of an ordinary Stromatopora. I had photographic representations of such natural surfaces on the plates pertaining to my old manuscript essay on Stromatopora, besides figures of vertical sections which exhibit the structure better than any description can do it.

As a second aberrant form of Stromatoporoids the authors pointed out a form to which they gave the name Pachystroma.

The type form occurs in the Niagara group and is described as consisting of subhemispherical masses formed of a concentric succession of very thick laminæ from one to two lines in diameter, which are in direct contrast, not separated by inter-laminar spaces except occasionally by narrow irregular intervals, consequently there are also no radial pillars. Under the microscope the great laminæ are formed of an indistinct porous calcareous tissue principally composed of irregular vertical fibres placed at some distance from one another, and only clearly brought to view by the use of polarized light. Numerous delicate but irregular, generally remote vertical vermicular tubules without distinct walls are said to perforate the mass, but such pores could not be discovered on fractured surfaces by the use of a simple lens. The surface of weathered specimens also shows radiating branched subdermal canals placed round numerous independent centres, precisely as in the so-called Conostroma.

Several figures of sections through Pachystroma are given, which, together with the above description, convince me that the authors had under observation imperfectly preserved specimens of Stromatopora, which occur abundantly in the Niagara group ; those found in the vicinity of Lockport in calcified condition, particularly correspond with the given descriptions. They have generally lost the finer structure, but exhibit distinctly a composition of concentrically superimposed bands consisting of an almost structureless, compact, calcareous mass, cut into thin slices, showing under the microscope the above described fibrous texture.

On examination of a good many specimens exceptionally a spot may be found in which the structure is better preserved, and in 
those I can see that each one of the described large, thick laminæ consists of a number of delicate subordinate laminæ, separated as usual by minute interlaminar spaces, intersected with pillars. In my opinion, therefore, the so-called Pachystroma merely represents a certain imperfect state of preservation of several of the ordinary species of Stromatopora found in the Niagara group. The grouping of the smaller structural elements into broader bands is almost universally the rule in Stromatopora. Any vertical section almost, in which the delicate laminæ and interstitial spaces alternate through the whole thickness of the mass with great uniformity, will, if we direct our attention to it, show a grouping of a number of such laminæ into one broader, occasionally narrower bands, discernible by a darker shade of color on the junction line of two of such bands. It indicates temporary short interruptions in the regularity of the progressing growth, as I have intimated previously, while giving a description of the structure of Stromatocerium.

Prof. Nicholson considers also Stromatopora densa of the Helderberg group as a representative of his Pachystroma, but of this form I can most positively assert that its structure does not differ in any respect from the typical forms of Stromatopora.

The specimens before me allow the recognition of the regular superposition of laminæ, supported by galleries of short, stout pillars with greatest distinctness; the orifices of the horizontal channel expansions are in vertical sections, rather large, and the ordinary interlaminar cell-spaces unusually small, which causes the compactness and apparent density of the mass, as compared with the open porous appearance of sections of other associated forms of Stromatopora, the commonest of which is Stromatopora ponderosa, Nicholson. This latter form I had years ago distributed among my scientific friends under the name of Stromatopora tentilis, on account of its most elegant reticulated appearance in vertical sections. In this respect it exceeds in distinctness any other form of Stromatopora known to me.

A third group of Stromatoporoids, aberrant from the ordinary type, Mr. Nicholson named Clathrodictyon. It is distinguished from the type form by the flexuose course of the lamellæ composing the laminated section. They are continually turned up and downward, the upturned portions representing the vertical pillars of ordinary forms of Stromatopora. The interlaminar 
spaces, therefore, appear as layers of rounded or elongated vesicules somewhat resembling the tissue of Cystiphyllum on a minute scale. Forms of this structure occur abundantly in the Niagara group and some in the Devonian strata.

A generic distinction of these forms, represented in many different modifications, can, in my opinion, be made with propriety, but as intermediate forms occur, in which the lamellæ are only little disturbed in their straight course by the inflexions representing the interstitial pillars, it is difficult to draw a line separating Clathrodictyon from Stromatopora.

Prof. Nicholson's type form of Clathrodictyon, occurring in the Niagara group, is described as forming large cake-like expansions from one to two inches in thickness centrally, but thinning out near the margins. Upper face irregularly undulating and exfoliating concentrically round elevated points. Surface smooth. Internal structure exceedingly delicate, formed of fine close-set, horizontal or slightly undulating laminæ, of which about twenty to twenty-five occupy the space of one line. Interlaminar spaces divided into minute lenticular cells formed by curved inflexions of the horizontal laminæ.

Specimens to which, in a general way, this description is applicable, are common in the Niagara group of Michigan, Kentucky and Iowa, but although a good many hundreds came under my observation I could never find one whose structure was so minute as to exhibit from twenty to twenty-five laminæ on the space of one line. The most delicately built among my specimens had not over sixteen within the space of a line.

The form having this delicate structure I had, in my abovementioned essay on Stromatopora, described and figured under the name Stromatopora minuta. Its structure does not represent the character of Clathrodictyon in its most perfect development, as the lamellæ, which by their inflexion form the pillars, are not much twisted out of their rectilinear general direction, and as a number of pillars are observable in such sections which are papillose prominences of the surface of the lamellæ, not showing any inflexion of the latter at their base.

Associated with this form are several other forms of much coarser structure with from six to eight lamellæ within the space of one line, which exhibit the clathrodictyon character in much more ideal perfection than the type form does. These had been 
described in my before-mentioned essay under the name of Stromatopora vesiculosa, as their vertical sections appear as an accumulation of layers of cystose cells, rather than as a succession of continuous laminæ, separated by interstitial spaces. The demarkating walls of the cells appear in vertical sections as the meshes of a net-work bounded by lines diagonally intersecting the direction which the laminæ should have if they formed continuous leaves. In some of these specimens a banded structure is observable, whereby from five to eight layers of vesicules are grouped together to form a broader band, which then is sharply defined by a straight continuous division line from the adjoining similar bands above and below it.

Other specimens of this vesiculose species of Stromatopora are found intergrown with stems of Syringopora filiformis, sometimes also with stems of Diphyphyllum multicaule, exactly in the same manner as in the previously mentioned Devonian forms, which have been subordinated by the authors to Caunopora, supposing the enveloped stems to be part of the skeleton of Stromatopora.

Among the Devonian representatives of his genus Clathrodictyon, Mr. Nicholson describes, under the name C. cellulosum, a form which I had in my paper named Stromat. cellulifera. It occurs in the corniferous limestone of Port Colborne and elsewhere, in association with another form which I called Str. invaginata, but which, it seems, did not come under his observation. C. cellulosum is described as growing in irregular expansions of considerable size, formed of a succession of horizontal lamellæ, about four occupying the space of one line, and so inflected as to form complete or incomplete partitions, which divide the interlaminar spaces into a number of irregularly oval vesicules, about three occupying one line. Surface tuberculated or granulated; the tubercules occasionally perforated. In the specimens found in the same locality the surface, instead of being tuberculated or granulated, as above described, is covered with roof-like, elongated, laterally uniting crests, forming in this way a network, enclosing shallow subpolygonal cell-pits, somewhat similar to the shallow pits of a minute compound star-coral, as the margins of these crests on weathered silicified specimens, being of porous texture, appear sometimes crenulated, which crenulation increases the resemblance. The other form allied to 
Clathrodictyon which is not described by Prof. Nicholson, presents the weathered surfaces of the silicified specimens, covered with very stout rounded conical papilli of almost uniform size, about half a millimetre in diameter and twice that distance apart. Apices of the not cross-fractured papilli imperforate. In a vertical section four or five well-demarkated stout lamellæ occupy the space of two millimetres, which is approximately the same as one line. The interlamellar pillars are formed by upward flexions of the lamellæ, and therefore we see the base of each one excavated by an inverted funnel-shaped sinuosity; and as the pillars of the successive laminæ correspond, the apices of the pillars of the inferior laminæ become invaginated into the basal funnel-shaped excavation of the next ones above, which being the case through the whole thickness of the laminated mass, makes it appear as if so many vertical columns intersected it transversely. This structure was observed by Mr. Nicholson in another species of Stromatopora, and induced him to propose for it the generic name Stylodictyon.

The space between these pseudo-columns is bridged over by a gently downward curved portion of the lamellæ, leaving correspondingly large elongated interlaminar spaces between them, which often are subdivided by arched vesicular plates obliquely and irregularly traversing them. The mode of growth of this form is the same as that of the former species; it occurs in thick undulating expansions, covered by an epithecal crust on the under side.

An associate of these two forms, which I had named Stromatopora explanata, has been described by Prof. Nicholson under the name of Stromatopora tuberculata. Its surface is crowded with rather close-set, rounded papilli, somewhat differing in size. Occasionally an arrangement of somewhat compressed, elongated papilli, in radial order towards certain centres, is faintly indicated, but rarely becomes obviously developed. The lamellæ are stout, formed of a compact tissue-mass, in which distant perforations are observable, maintaining communication between the superimposed interlaminar spaces. Five or six lamellæ occupy the space of one line, interstitial cell-spaces comparatively large, oval or elongated to twice the amount of their height. The course of the laminæ is generally in straight parallel lines, but we can often observe their upward inflection at the base of some of the pillars. This produces in vertical sections of this form a 
considerable resemblance to sections of Clathrodictyon cellulosum, whose structure is somewhat coafser, having only four or five lamellæ within the space of a line, and more conspicuously inflected in order to form pillars.

As a fourth aberrant form of Stromatoporoids, a single specimen found in the upper Cincinnati group of Ohio is described by the authors, about which I am unable to give an opinion of my own, as from the rather vague description I cannot say that anything similar ever was under my observation.

After these expositions, a classification of the different types of Stromatoporoids is attempted, and seven generic cadres are proposed, most of which had been sketched already in the previous chapters.

These proposed genera are: (1) Stromatopora Goldfuss, comprising all those forms consisting of concentrically superimposed laminæ, each lamina separated from the other by a distinct interlaminar space, which is crossed by numerous vertical pillars. In some of these forms are radial, subhorizontal canals or surface grooves placed round minor centres, which, according to my own experience, are present in almost every form of Stromatopora-at least, in rudimentary development. In addition to these characters, large vertical canals intersecting the laminated masses are described by the authors, which they believe to be analogous to the oscula of sponges. I have to reject this opinion as erroneous.

(2). Caunopora Phillips. Type, Caunopora placenta. Representative form of the authors' Stromatophora perforata. I need not enter again into a discussion of the value of this generic distinction, as I have previously proved that these forms do not represent one organism, but are coral stems, parasitically invested with various kinds of Stromatopora, which in the same localities grew perfectly free of such enclosed stems, erroneously believed to be parts of the organism.

(3). Clathrodictyon Nicholson, likewise, has been sufficiently taken into consideration.

(4). Stylodictyon Nicholson, is represented by two species, St. columnare and St. retiforme. Besides the general structure of Stromatopora, as special character of this genus, it is asserted that a system of vertical columns of dense calcareous tissue pervades the laminated skeleton. The concentric arrangement 
of the successive laminæ and their interstices round these vertical columns, is also brought forward as a noteworthy circumstance. It is likewise stated that radiating channel expansions may be present or not. I had described and figured these two forms in my paper, under the name Stromatopora Wortheni, thinking a division into two species superfluous, as insensible gradations from one form into the other exist.

The columellar streaks, seen to intersect the mass of this otherwise typical form of Stromatopora in vertical sections, are produced by the repeated abrupt flexions of the lamellæ in papillose prominences which cover the surface, similar to those we observe in many other forms of Stromatopora, as for instance, in Str. pustulifera Winchell.

As in this latter form, the prominences are somewhat larger and consequently the flexions are not so abrupt, and as the tissue of this form is throughout more compact, we do not observe an obvious contrast between the density of the parts corresponding with the papillose prominences and the broader downward-curved intermediate portions of the skeleton, while in the so-called Stylodictyon, the abrupt flexions of the lamellæ in the papilli into an almost vertical direction, cause the closer approximation, and consequently greater density, of these parts than of the intermediate gently downward-curved portions of the laminated skeleton which have comparatively open, well-defined interlaminar cell-spaces contrasting with the denser portions, so as to let them appear under the form of vertical columns. Examining transparent vertical sections of such specimens, we see that the lamellæ are not interrupted in their continuity while passing across these columellar streaks, and that no additional tissue element comes into play, which could be claimed as constituting the substance of the columelles. On the contrary, every portion of these columellar streaks is identifiable either as a normal part of the lamellæ or of the intermediate system of pillars. To mention among the generic characters the concentric arrangement of the lamellæ and their interstices round these columellar centres, appears to me rather superfluous, as it is a necessary consequence of the monticulose prominences into which the surface is raised. I could invariably observe in all specimens of this tribe which came under my observation, radial horizontal ducts, which, by the authors, are said to be sometimes developed and sometimes not. 
The structure of the form called Stylodictyon columnare, found in the Helderberg limestones of Kelley's Island, etc., is somewhat more compact than we find it in the specimens of the Hamilton group named retiforme, but there occur numerous transition forms from the compact to a more open, porous structure. In the size of the papillose prominences, also, a great variation of forms exists. I think, therefore, we could well spare one specific name and retain the one I had selected for both varieties jointly, Stromatopora Wortheni.

In the Helderberg limestones of Vernon, Indiana, and at the Falls of Ohio, oceurs a form of Stromatopora very similar in structure with the former, but with columellar streaks much smaller than in these, measuring only half a millimetre in diameter, or little over. Its tissue mass is also more bulky, of open reticulated spongious texture plainly recognizable with a common hand magnifier. I had given in my manuscript description and figures of it, under the name Stromatopora granulifera, as the papilli on its surface give it rather a granulated than papillose aspect, on account of their smallness. Horizontal radial ducts are well developed in this form. In it and in the former species these ducts unite in more or less distant centres, which are totally independent of the papillose prominences of the surface, while in many other forms of Stromatopora, as for instance, in monticulifera and pustulifera Winchell, the apex of each of these monticulose elevations is also the centre of convergence for such channels.

Under Nos. 5 and 6, generic descriptions of Stromatocerium and of Pachystroma are given, which require no further critical comment, as I have on a previous page sufficiently expressed my views on the correctness of the emended characteristic of Stromatocerium and of the merits of the distinction of Pachystroma.

As a seventh generic form of Stromatoporoids a certain concentrically laminated fossil found in the Niagara limestone of Louisville, Ky., has been described by Mr. Nicholson under the name Dictyostroma, which has nothing in common with the Stromatoporoid tribe, excepting an external resemblance, being composed of a succession of laminæ separated by large interstices. The upper surface of these laminæ is covered with spiniform prominences, part of which are long enough to reach the bottom of the superincumbent lamella; others are shorter. 
These numerous processes vertically intersecting the interlamellar spaces increase the resemblance of these fossils to Stromatopora. Each of the undulating superimposed laminæ, of not quite one millimetre in thickness, and about from one to three millimetres distant from one another, is composed of a layer of horizontally prostrate tubules with solid intimately united walls, which after some extent in the horizontal position, abruptly bend upward and open on the surface of the laminæ with oblique compressed orifices bordered on the outside either by a sharp lip, or by a vertically rising strong proboscidal prolongation, similar to the pillars on the surface of the lamellæ of a Stromatopora. The underside of each one of these lamellæ in the concentric succession, is covered by a wrinkled epithecal crust, through which the outlines of the single tubules composing the lamella are plainly visible, just as we see it on the underside of foliaceous expansions of Alveolites, and indeed, the structure of this fossil in every respect corresponds with the structure of Alveolites or Limaria, and has no analogy whatever with Stromatopora.

As the numerous specimens I possess of this fossil were not only found in the same locality from which Prof. Nicholson's type specimen comes, but were collected at the same time when Rev. Mr. Herzer picked up the specimen now in possession of Prof. Orton, of Ohio, I am positive that the objects I have under consideration are identical with Prof. Nicholson's type specimen.

A very similar concentrically laminated fossil, but on the whole of coarser structure, with interlaminar spaces from three to five millimetres in width and with very stout intervening pillars is not rare in the drift deposits of Ann Arbor. The specimens are silicified and the structure of the laminæ, as being composed of a layer of prostrate tubules, is no longer recognizable. The wrinkled epithecal crust on the underside of each lamina is, however, still well preserved. The pillars, if broken through, exhibit sometimes a central channel; the shorter ones, not injured, are imperforate at the apex; some of the larger pillars divide into mammiform side branches. There remains no doubt in my mind that this and the former Dictyostroma of Nicholson belong to the tribe of Alveolites, Limaria, etc. I propose, therefore, for them the name of Alveolites stromatoporoides.

A genuine Stromatoporoid which in its external aspect has 
some resemblance to Mr. Nicholson's Dictyostroma, is found at the same locality at Louisville, but the descriptions given by Nicholson, and his figures, sufficiently prove that it was not this form which served him as a type for Dictyostroma. The rather closely approximated laminæ are inflected upwards to form stout conical pillars with a funnel-shaped excavation at their base, as in Clathrodictyon and in Stylodictyon of Nicholson. The pillars of the superimposed laminæ correspond, and the apices of the lower pillars become invaginated into the basal cavities of those above, whereby a sort of pseudo-columns are formed which vertically intersect the entire thickness of the masses, growing in flat expansions and covered with an epithecal crust on the underside. A number of other interesting forms of Stromatopora occur in the Niagara group, but as my present intention is only a review of Messrs. Nicholson and Murie's work, I abstain from their description on this occasion. 


\section{$2 \mathrm{BHL}$ Biodiversity Heritage Library}

1886. "On the Minute Structure of Stromatopora and Its Allies." Proceedings of the Academy of Natural Sciences of Philadelphia 38, 39-56.

View This Item Online: https://www.biodiversitylibrary.org/item/17721

Permalink: $\underline{\text { https://www.biodiversitylibrary.org/partpdf/85266 }}$

\section{Holding Institution}

MBLWHOI Library

\section{Sponsored by}

MBLWHOI Library

\section{Copyright \& Reuse}

Copyright Status: Public domain. The BHL considers that this work is no longer under copyright protection.

This document was created from content at the Biodiversity Heritage Library, the world's largest open access digital library for biodiversity literature and archives. Visit BHL at https://www.biodiversitylibrary.org. 